\title{
FEATURES AND ISSUES OF URBAN INDUSTRIAL BATIK CLUSTER DEVELOPMENT IN SURAKARTA AND YOGYAKARTA, INDONESIA
}

\author{
スラカルタ市とジョグジャカルタ市におけるバティック産業クラスター開発の特徴と課題
}

\section{K. Nurul HANDAYANI*, Takeru SAKAI** , Atsushi DEGUCHI*** and Prasanna DIVIGALPITIYA****}

\author{
クスマニンディヤヌルハンダヤニ, 坂 井＼cjkstart猛，出口＼cjkstart敦，プラサンナディビガルピタヤ
}

This paper discusses the neighbourhood asset management for community's sustainability in the cities of Surakarta and Yogyakarta, in Central Java, Indonesia. The combination of urban heritage and traditional industry is a potential issue in sustaining urban heritage. First, we identified three selected sites in the areas of Laweyan, Kauman and Tamansari as the Batik cluster industries in urban heritage areas. Second, the historical development process of the Batik industry was clarified and stressed during the revitalization phase (1998-Present) using timeline analysis. Third, in order to clarify how the Batik industrial cluster function in the community, studies of current conditions by comparison of each cluster's neighborhood asset management have been conducted. Three factors have been analyzed human capital, development market, and social capital. Subsequently, trough the development phases of Batik Industry, there were several factors that caused changes to the Batik handmade production such as technologies, policy and changing life style. The functioning neighborhood asset management in all three sites is as traditional home base-production. Furthermore, the issues facing all three of the sites in this study are the performance of the forum as a knowledge-sharing agent, and as a platform for organizing the Batik industry and managing tourism within urban heritage sites. Based on these findings, the conservation of the cultural identity of the production process and local identity of settlements are vital elements of Batik marketing within urban heritage.

Keywords: Batik, Industrial Cluster, Small Medium Enterprises, Heritage, Management, Indonesia バティック，産業クラスター，中小企業，遺産，マネジメント，インドネシア

\section{INTRODUCTION}

\subsection{Background}

In terms of the built environment, most of the policy focuses on physical development. On the other hand the revitalization of the historic cities needs to be managed actively to ensure their sustainability with the proper management both in physical and non physical assets. This is in line with Allen et.al ${ }^{1)}$, managing neighbourhood assets is a crucial element to achieving sustainable communities, but often neglected in many cases in revitalization of urban planning. According to Manzi et.al ${ }^{2}$, the nature of sustainable development is complex and dynamic. It's incorporating management of social, cultural, economic and community dimensions. Thus neighbourhood asset management is crucial to managing and adding value to community assets.

According to Stainberg ${ }^{3)}$, urban heritage has something of value not only of tangible heritage "monument", e.g. palaces, historic settlements, religious buildings, but also non-tangible elements such as customs, cultures and beliefs which play a role for the articulation of space use and the built environment. The cities of Surakarta and Yogyakarta are the result of the split from The Mataram Kingdom in 1755 (Fig. 1). As an urban heritage in Java, Indonesia, both cities are in the center of Javanese culture and share an intangible heritage asset of Batik. The skill of Batik production and the process of production is a heritage- based industry. All goods are processed and assembled by hand. Craftsmanship and knowledge is passed through families from generation to generation. Generally the Batik workshops are located in the houses of the proprietors within clusters ${ }^{4}$.

Over more than half century, handmade Batik industries have emerged in of Surakarta and Yogyakarta cities. Both cities faced revival and declining periods of Batik Industries in the past. Today, manufacturing and trade and tourism service industries are the largest sectors in the economic structure of Surakarta City. Surakarta's gross domestic product is accrued from manufacturing (24.1\%) and trade and tourism services $(24.2 \%)^{5}$. In Surakarta City $90 \%$ of manufacturing industry output is from small to medium enterprises (SME) that includes the Batik industry ${ }^{6}$. Meanwhile in Yogyakarta, the gross domestic product is accrued mostly from trade and tourism services (25.8\%) followed by the manufacturing industry $(11.3 \%)^{7}$. The development of Batik industry was influenced by the tourism demand. Thus, the managing neighbourhood asset of urban heritage and heritage based industries in both cities becomes a potential issue in urban economic development and urban sustainability. Against this backdrop, we give an overview of how neighbourhood asset management in Batik cluster industries has revitalized urban heritage.

\footnotetext{
* Lecturer, Department of Architecture, Faculty of Engineering, Sebelas Maret University, Dr. Eng.

** Prof., New Campus Planning Office, Kyushu University, Dr. Eng.

*** Prof., Graduate School of Frontiers Sciences, University of Tokyo, Dr. Eng.

**** Assoc. Prof., Graduate School of Human-Environment Studies, Kyushu University, Dr. Eng.
}

セベラスマレット大学工学部建築学科 講師・博士(工学)

九州大学新キャンパス計面推進室 教授・博士(工学)

東京大学大学院新領域創成科学研究科教授. 工博

九州大学大学院人間環境学研究院 准教授・博士 (工学) 


\subsection{Objective}

This study emphasizes the broad context of revitalization industrial Batik clusters in urban heritage areas as well as their neighborhood asset management to achieving sustainable communities harmonized with historical properties. The objectives of this study are as follows:

1) To clarify how Batik industries and the community have changed throughout the history.

2) To clarify how the Batik industrial cluster functions in the community.

3) To discuss the critical issues for the sustainability of industrial Batik clusters in the cities of Surakarta and Yogyakarta.

\subsection{Previous Research}

There are several studies emphasizing the importance of neighborhood asset management in urban planning by Allen et.al ${ }^{1)}$ and Power $^{8}$. These studies have shown that neighbourhood asset management is an integral part of managing anything that is useful and of value in order to achieve social sustainability in urban areas. According to Allen et.al ${ }^{1}$, there are five capitals values in neighbourhood asset management distinguished by natural, social, human, manufactured or physical and financial capitals. However, both Allen and Power do not clearly define the organization of neighbourhood asset management within the context of cluster industries. Meanwhile, many studies exist on industrial clusters. Morosini ${ }^{9}$ and Scott ${ }^{10)}$ explain industrial clusters as a geographic cooperative group organized around their own centre of gravity. Morosini defines three broad factors of industrial clusters: internal, external and social.

Among studies that focus on urban heritage, Stainberg ${ }^{3}$ discusses the rehabilitation of urban heritage in developing countries. According to Stainberg, the rehabilitation and revitalization approaches are needed to maintain the typical urban issues, essential qualities of the historic areas and of the life of the communities.

\subsection{Methodology}

Firstly, the sites which formed industrial clusters in urban heritage areas were selected. Three sites were selected in Laweyan, Kauman in Surakarta City and Tamansari in Yogyakarta which were Batik clusters in urban heritage areas (Fig. 2).

Secondly, in order to find how the community of industrial Batik has changed throughout history, we carried out a structured interview for 5 experts. Three leaders from local initiative organizations that related with Batik (called forum in this paper). One officer of Surakarta City government from Department of City Planning was selected for her knowledge in current activities and project of revitalization in Laweyan and Kauman. academician from the Faculty of Social and Political Studies Sebelas Maret University of Surakarta was chosen for the interview because his expertise on urban sociology and his knowledge on the development of Batik industry in Java Island. The academician from Sebelas Maret University and head of forum from Tamansari were selected for their knowledge of Batik development in Yogyakarta. The interview was conducted on September $1^{\text {st }}-30^{\text {th }}, 2011$. The interview asked 5 questions about historical events, causes of those events, development of Batik markets and stakeholders involved. We also carried out a literature review and compiled information for those events. This is presented in the form of a timeline in order to analyze the development of each industrial Batik cluster. The interview was conducted on September $1^{\text {st }}$ $-30^{\text {th }}, 2011$. The interview asked 5 questions about historical events, causes of those events, development of Batik markets and stakeholders involved. We also carried out a literature review and compiled information for those events. This is
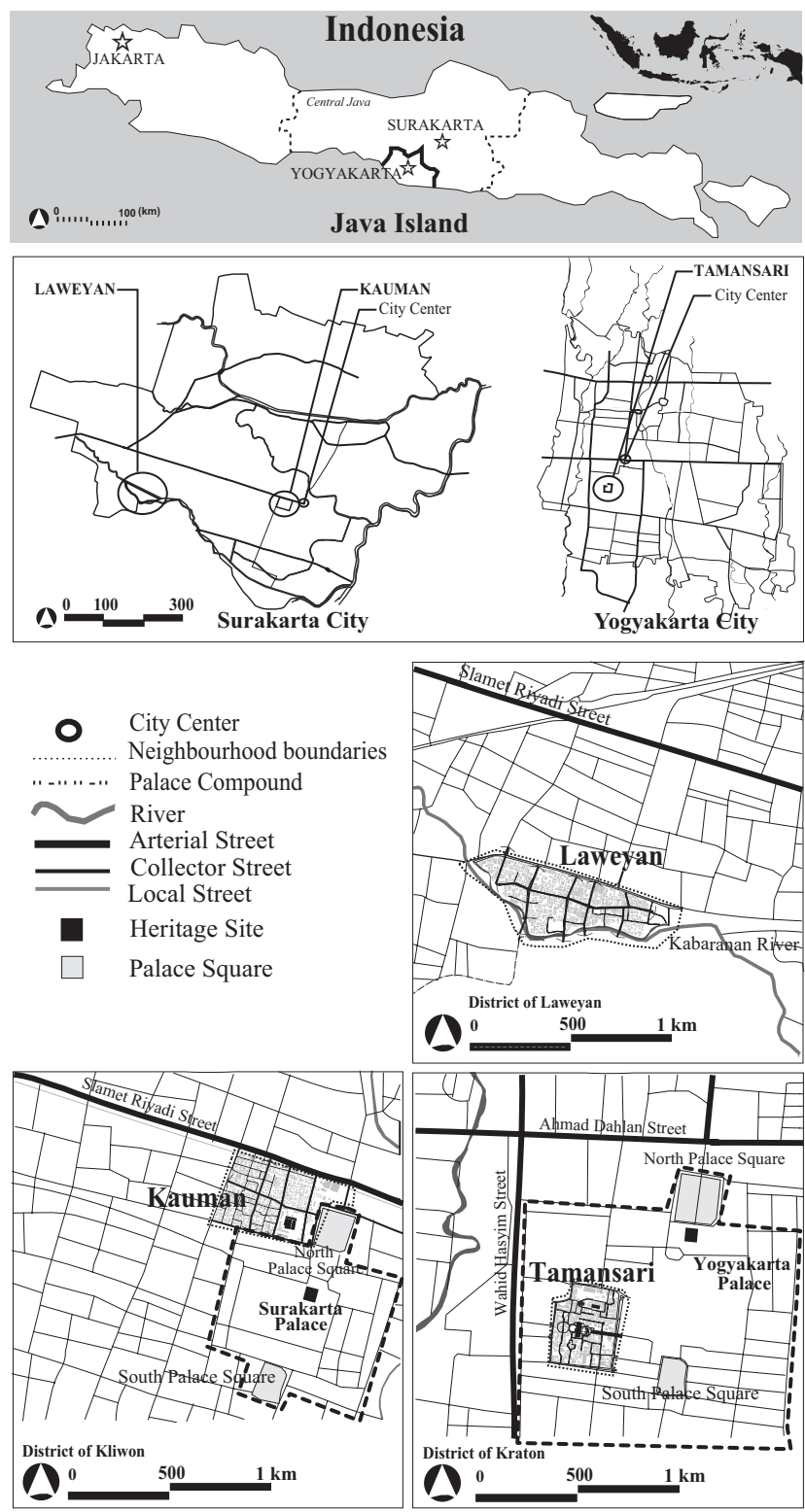

Fig. 1 Study Areas of Surakarta and Yogyakarta

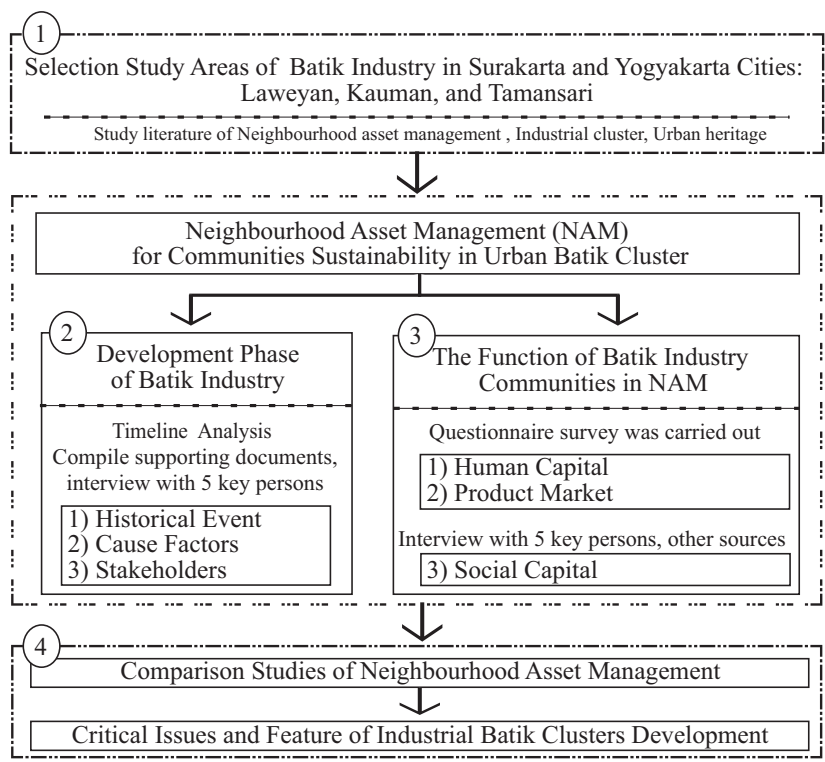

Fig. 2 Flow of this Study 
presented in the form of a timeline in order to analyze the development of each industrial Batik cluster.

Thirdly, a questioner survey was carried out in order to understand the functioning of neighborhood asset management trough structure of questioner in three case study areas (Fig. 3). According to Allen et.al ${ }^{1)}$ and Stainberg ${ }^{3)}$, this study will focus on human capital and social capital. These two components are dominant in each case study as an internal factor that is driven by local forces. According to Morosini ${ }^{9)}$ and $\mathrm{Scott}^{10)}$, the external factors that influence industrial Batik clusters are development of product markets which can be geographically localized either within the cluster or nearby.

From the questioners that were aimed at human capital element collected the information about human resources (owners and labor), process of Batik production and capabilities of business in each case study. The questionnaire contained questions about the composition of entrepreneurs, such us business ownership by gender and age, and ownership by business venue. Information of labor was collected about employment size and labour origin. In batik production process and capabilities, information about technology and supply chain, business type, business location, and sizes of home based enterprises were collected. Meanwhile in development of product market, information about customers was collected. Information about customers was collected for market distribution and tourism. The total number of Batik businesses in Laweyan was 90 enterprises. Out of these 44 have been rejected to participate in the questionnaire survey. A Total of 46 completed answers were collected from Laweyan. The total number of Batik businesses in Kauman was 57 total enterprises. Out of that 25 were rejected to participate in the questioner survey. A total of 32 completed answers have been collected from Kauman. Meanwhile in Tamansari there were 40 entrepreneurs according to the field survey. A total 7 entrepreneurs have been rejected to participate. A total of 33 completed answers were collected form Tamansari (Table 1). This survey gathered information from the owners of the enterprises. The questionnaire was conducted from September, $1^{\text {st }}$ to October, $30^{\text {th }} 2011$.

In order to analyze the social capital, the knowledge sharing was evaluated using information of initiatives by local organizations. We selected leaders of forum from each case study and interviewed them. The interview contents were about establishment process, members, activities, connection with stakeholders and obstacles. We also compiled various types of supporting materials such as newspaper articles, meeting minutes etc to describe the recent situation of the forum. The interview was conducted on September $1^{\text {st }}-30^{\text {th }}, 2011$. Lastly, we made comparisons based on the data. We made classification from remaining and changing values in order to identify the critical issues of neighborhood asset management in each case study. Finally, we explained issues of the neighborhood asset management Batik industrial cluster in urban heritage.

\subsection{Study Areas}

Three sites which formed clusters have been selected: Laweyan (20.56 ha) and Kauman (20.10 ha) in Surakarta, and Tamansari (12.66 ha) in Yogyakarta (Fig. 1). The selection of the study areas based on the formation of each cluster was related to the heritage value of the site and tourism destination reason. Kauman and Tamansari are located within an old Javanese city, which typically consists of palaces, squares (alun-alun), and markets (pasar). Kauman is located near the Kraton Surakarta Palace (tourism destination) and located about $0.5 \mathrm{~km}$ from the city center. Tamansari Water Castle, in particular, is inside Yogyakarta's Palace walls and is located about $2.5 \mathrm{~km}$ from the city center. Tamansari Water Castle was transformed into a royal servants settlement in 1867 after the big earthquake (Fig. 4). Since 1974, Tamansari cluster has become well known as a tourism destination of Yogyakarta Kraton Palace (Fig. 1). In Kauman and Tamansari, the skill of producing Batik was introduced from the Royal Family ${ }^{4}$. The greatest demand has been for traditional clothing and ritual articles.

Laweyan was an independent industrial center on the periphery of Surakarta city. The Kabanaran River is a natural component of the environment that demarcates the southern boundary of the Laweyan settlement. It is a feature among all three sites unique to Laweyan. Laweyan is located about 4 km from the city center (Fig. 1). By mayoral decision No. 646/11/1/1997 in 1997 ${ }^{112)}$, Laweyan was designated as a heritage settlement in order to conserve Batik houses built around 1913, as well as the merchant township with European, Chinese and Islamic architecture. Laweyan was a cotton industrial cluster which then developed into a Batik cluster due to market demand.

\section{DEVELOPMENT PHASES OF BATIK INDUSTRY}

According to Ramdhon ${ }^{13)}$, the political change has been seemingly occupied with demonstrating the existence of a transition of social change in Kauman. In line with Rebbeca ${ }^{4}$, the social changes in Indonesia have been occupied with diffused Batik production in Central Java, it's influenced by the new invention technology of Batik and also political reasons. Within such processes, the construction of time line analysis has become a requisite strategy based on political change in Indonesia, in order to find how community industrial Batik has changed throughout history. We utilized interview and several supporting documents to analyze the chronological change of industrial Batik development. The authors divided the period of Batik development into four periods. It's distinguished by political conditions in Indonesia. Phase I: the period of before and Mataram Kingdom control (1600-1800), Phase II: the Dutch colonial phase (1800- 
1945), Phase III: the period after independence (1945-1998) and Phase IV: the period after the reforms riots of 1998, the process of democratization and decentralization started in Indonesia (1998 - present). Further examinations can be identified by several periods below (Fig. 4).

\subsection{Phase I: The Period Before and Mataram Kingdom control (1600-1800)}

In the early 19th century, Batik manufacturing in Surakarta was influenced by the fame of the Mataram Kingdom which represented the cultural base of Javanese society ${ }^{11)}$. Batik production was processed and assembled by hand. The kingdom provided a demand and orders for Batik products, which served as a cultural symbol. The kingdom had control of Batik development, particularly in the Kauman area ${ }^{4) 1113)}$. Meanwhile Laweyan was the first industrial cluster for producing textile cotton in Surakarta City. It was established in 1546 before the Mataram Kingdom existed (Fig. 4) ${ }^{1112}$.

\subsection{Phase II: The Period of Colonialization (1800-1945)}

In 1850, Batik production became commercial mass products due to national demand and the innovations in technology ${ }^{4}$. The stamp for Batik or Batik Cap in Javanese was invented as an alternative to drawing. "Batik for sandang" or Batik convection was established. This development triggered the mass production of the Batik industry. Since 1850, Laweyan and Kauman started mass production and the Batik industry became the main occupation of the people as SME. In 1912, the association of Islamic local traders called Sarekat Dagang Islam in the region was established ${ }^{14}$. The association quickly expanded its batik commercial network from Laweyan to big cities all over Indonesia. Due to its rapid expansion, the Dutch Colonial Government then carried out a series of continuous economic and political pressures on the association. As a result, the indigenous Batik commercial network gradually became powerless. In 1930, there were 230 Batik enterprises in Laweyan, a fact clearly reflected in the physical settlements of Kauman and Laweyan ${ }^{4 / 2)(j) i i i)}$. Most of the Batik houses found today were constructed around 1913, and most of the Batik manufacturing workshops were constructed around $1930^{12) 15)}$. The peak production was reached in 1920. The construction of inland roads and railway opened up a new market enabling the emergence of urban-based Batik enterprises producing goods for mass consumption ${ }^{11)}$. It is the reason why in the1920's, the Batik industry started in the Tamansari area (Fig. 4) ${ }^{1116) \text { iv) }}$.

\subsection{Phase III: The Period After Independence Day (1945 - 1998)}

Since 1945, the numbers of SME's of Batik handmade production constantly decreesed ${ }^{4) 14}$. Post-independence political and development policies had a large impact on the SME's Batik businesses. Among the issues were political issues, textile policy, competition from well-financed of big company, and producing Batik using modern Batik printing technology ${ }^{4) 13 i j i i)}$. Lack of access to current markets and the changing lifestyle of business were major reasons for the decrease during the period from 1970-2004 ${ }^{11 \text { ijiii) }}$. To safeguard against the decrease of the Batik industry in 1960, the Indonesia government established the All Indonesia Batik Cooperative (GKBI) in 1953 $3^{4) 14}$. 1990 was the year where most SME's Batik industry closed in Laweyan. By 2003 there were only 10 enterprises remaining in Laweyan ${ }^{14 i j}$. Meanwhile, in the 1970s, tourism in Yogyakarta became a lucrative market. The driving factor of the Batik industry in Tamansari was tourism in the Tamansari Water Castle ${ }^{4 \text { iv }}$. In 1974, Tamansari was officially opened as national tourism destination. By facilities in major tourist centers like the Tamansari water castle heritage site area, a number of Batik producers began to market their goods directly to retailers or even consumers, reducing the role of middle-sized entrepreneurs in the Batik market ${ }^{16) i v}$. In the same year Tamansari already had the community initiative KALPIKA. The aim of KALPIKA was the center of education for tourists or students to learn Batik (Fig. 4) ${ }^{\text {iv }}$.

\subsection{Phase IV: The Period After Reforms Riot (1998-Present)}

In this period, the local government structure went through its biggest transformation change due to the decentralization process ${ }^{17)}$. Surakarta City is promoting the symbolic importance of Batik by conserving Surakarta's heritage assets ${ }^{v}$. Governments have pursued policies aimed at fulfilling the revival of the handmade Batik industry through local meetings, cooperative schemes, and physical structural neighborhood improvements. During the period 2005-2010, in Laweyan first and Kauman later, the Surakarta City government was invested in the public domain, in things such as signage, pedestrian way greenery, street furniture, and recycling waste ${ }^{v}$. In 2010, the government city followed-up on pedestrian improvements to create a "Batik walk" inside the compound of Laweyan and Kauman ${ }^{\mathrm{iiivv}}$. The purpose of all these projects was to improve the environments for residents, Batik producers, and tourists. The city has been

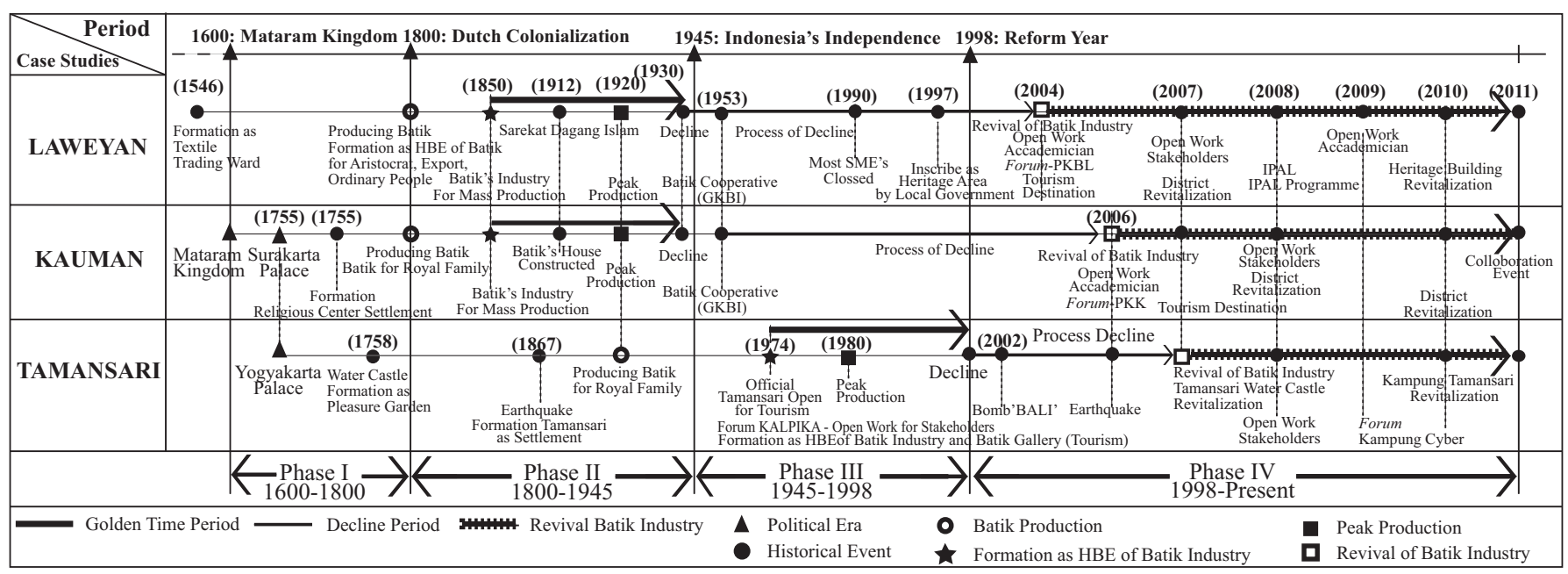

Fig. 4 Development Phase of Industrial Batik Clusters 
sponsoring cultural programs at Laweyan and Kauman, including the Solo Batik Carnival, since 2008, as well as international performing arts festivals ${ }^{\mathrm{v}}$. The declaration of the Laweyan area as an industrial Batik heritage site, and as a tourism destination was in 2004. In the same year, Laweyan began open relations with stake holders and the forum was established to promote tourism ${ }^{\text {i) }}$. The same spirit to revive Batik industry happened in Kauman. In 2006, Kauman was inaugurated as a tourism destination for Batik Industry. The number of Batik enterprises in Kauman and Laweyan has slightly increased since local governments started supporting the promotion and infrastructure development within these areas. In Laweyan, by 2008 there were 60 enterprises $^{5)}$. In Kauman by 2008 there were 40 enterprises. Meanwhile in Tamansari after the physical revitalization the environment inside the castle support to attract more tourism visited Tamansari industrial Batik. The forum Cyber Batik in Tamansari started to actively make campaigns and promotions (Fig.4) ${ }^{\text {iii) }}$.

From the chronological time line, there were several factors that caused changes to the Batik handmade production such us technologies, policy and changing life styles. In phase I: the Batik producing was based on handmade production. In phase II: the coming technology with stamp that influenced Batik production started the mass production. In phase III: the coming new technology of Batik printing with the machine influenced Batik's handmade production to decline. In phase IV: 6 years after reforms, the year 2004 was the revival period of the Batik Industry. Handmade Batik production was revived. Phase IV: becomes important because there were a lot of activities regarding the revitalization programme promoted by various stakeholders for handmade Batik production. According to this situation we would like to examine how the neighbourhood asset management has governed functioning in the revival of industrial Batik clusters.

\section{THE FUNCTION OF BATIK INDUSTRY COMMUNITIES IN NEIGHBOURHOOD ASSET MANAGEMENT}

In phase IV, the process of democratization and decentralization started in both cities. Decentralization gives the local government and citizens a chance to take initiative efforts in various fields. Therefore Batik clusters in Surakarta and Yogyakarta cities were revived. In this section, the key factors that govern the functioning of neighbourhood asset management of the Batik Industry in phase IV were examined.

\subsection{Human Capital}

Industrial Batik clusters are geographic cooperative groups based on heritage-based industry that include their own suppliers, consumers, and peripheral supporting industries. The formation of industrial Batik clusters are group of business within the same areas and near each other. The key factor in generating these industries is resource of human capital. Within the human capital element we are talking about human resources. Human resources were analyzed through the composition of entrepreneurs. The composition of entrepreneurs was analyzed by several elements such as production age, dominance of gender, ownership of business venue, employment size and labour origin. The average age of owners was 35-60 years old in all three sites, $17.4 \%$ of business owners in Laweyan were above 60 years old (Fig. 5). Composition of labor was analyzed by employment size and origin of labor. Females are the dominant gender in ownership of firms in Kauman (56.3\%) and Laweyan (58.7\%) (Fig. 6). In contrast to Laweyan and Kauman, the majority of business owners (69.7\%) in Tamansari were male. This condition caused by the shift in male employment patterns from farming to employment in the urban informal sector and unskilled levels in the commodity trade, crafts, and food processing due to decreasing rice

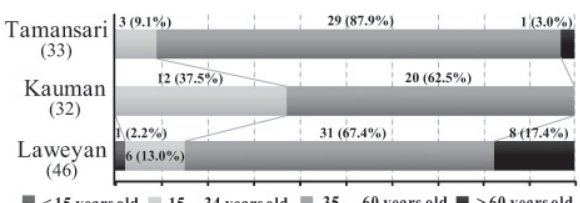

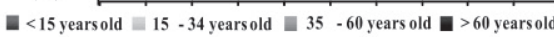

Fig. 5 Ownership by Age

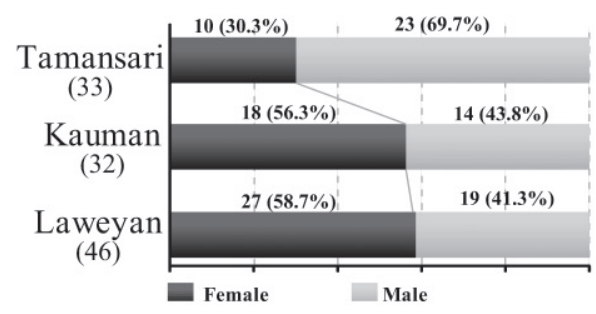

Fig. 6 Business Ownership by Gender

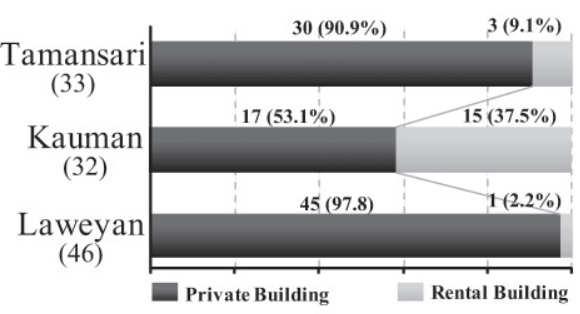

Fig. 7 Ownership by Business Venue

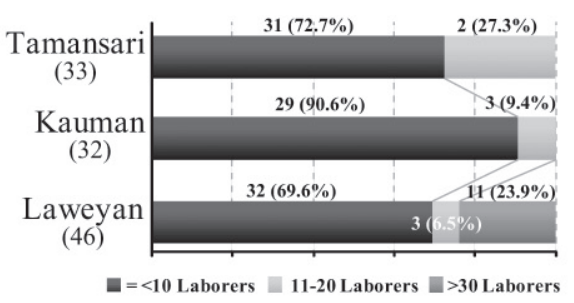

Fig. 8 Employment Size

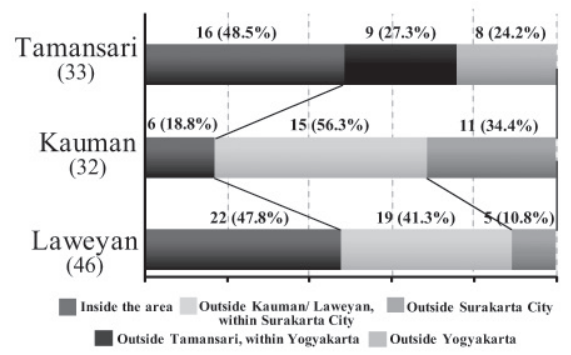

Fig. 9 Labour Origin production in Java ${ }^{4}$. Kauman has the highest percentage $(37.5 \%)$ of business venues in rented buildings. This demonstrates that the Kauman cluster has the highest number of entrepreneurs from outside the area (Fig. 7). Most of the Batik industries in all three sites were small enterprises with less than 10 laborers. In Tamansari, 72.7\% of businesses had less than 10 laborers and Laweyan has the highest number of businesses with more than 30 laborers (23.9 \%) (Fig. 8). Although 27.3\% of Tamansari businesses have 11-20 laborers, most of these businesses have their workshops outside the kampung area. Nearly half of the laborers in Laweyan and Tamansari live and work within the cluster area. In Kauman, the majority of the laborers live outside the cluster area (Fig. 9).

\subsection{Process and Capabilities}

Under human capital we are talking about process and capabilities. The production process of handmade Batik as a whole generally consists of six basic 
steps: (1) pattern-making, (2) the waxing process, (3) dyeing, (4) removing the wax, (5) tailoring (designing clothes, cloth-cutting, sewing, finishing), and (6) sales. From the field survey, it was discovered that there are two types of production processes. In the full Batik process, the whole production process is carried out in the same workshop. This type of production is referred to as "factory-based production". Half of the production process was carried out outside the site area. In both situations the finishing and selling of products are conducted within the site areas. Batik workshops can be classified into six categories based on the production process, such as workshop, apparel, gallery, workshop and gallery, apparel and gallery, and full production company of Batik. The majority of businesses in Kauman are galleries (81.3\%). In Laweyan, $13.0 \%$ are full production businesses. The galleries are the dominant function in every site. In Tamansari, 20.6\% of entrepreneurs own workshops and galleries. This demonstrates the diversity of business types in Batik production (Table 2). The diversity of Batik production businesses is also visible in spaces used for different activities. In Kauman, $40.6 \%$ of production is carried out in special rooms, an expansion of the main house used for Batik production. In Tamansari, 12.1\% of production is carried out in special spaces within the compound, and the majority of production activities are carried out in living rooms (45.5\%). One unique feature of Laweyan is that $21.7 \%$ of businesses have their own factories. HBEs are informal sector economic activities that operate from the house. The total size of an HBE is determined by the technology and production processes that occur in each business. Laweyan has a bigger mean size of workshop production and living area than Kauman or Tamansari (Table 2).

\subsection{Development of Product Market}

Tamansari has the widest range of suppliers, including foreign countries. Kauman relies mainly on local suppliers for materials. Laweyan's supplier base, which includes Java, is wider than that of Kauman. The majority of suppliers come from within the city area. Only in Tamansari did $12.0 \%$ of businesses source some of the raw material from foreign countries (Fig. 10). Tamansari exports $24.2 \%$ of their products to foreign countries. Kauman and Laweyan still have demand from local markets. Big firms in the Laweyan cluster area have wider access to markets on Java Island (Fig. 11). Kauman (75.0\%) and Tamansari (75.7\%) have the benefit of the tourism industry. Promotion from the tourism industry has a direct effect on most entrepreneurs (Fig. 12).

\subsection{Formation of Batik's Community}

From the chronological time line analysis, we recognized that in each phase there is a different connection between Batik entrepreneurs, Batik community and stakeholders. There has been a change in community functioning of Batik industry in three cases (Fig. 13). In phase I, there was no relation between entrepreneurs with any stakeholders. In phase II, the entrepreneurs had established the association of local traders but due to the Dutch political power becomes powerless. In phase III, the Indonesia government established the Batik Cooperative to support Batik Industries. The Batik community development in Surakarta was not initiated by the local community. Meanwhile in Tamansari the condition was revised. The Batik community was established by a group of Batik entrepreneurs. In Phase IV, Laweyan (2004) and Kauman (2006) established the forum $^{1}$. Members of forum are Batik entrepreneurs, Batik entrepreneurs groups (Batik Painting, Batik Clothing) and local community relate to the Batik industry. The establishement of forum was initiated by various stakeholders. Meanwhile in 2007, Tamansari formed forum in order to revive from the lack of tourism caused by the big earthquake $\mathrm{e}^{\mathrm{iv}}$. The establishment of Batik community in Tamansari was initiated by local people similar to Laweyan and Kauman in Surakarta City.There were a lot of activities regarding the tourism and the Batik's empowerments were supported by different stakeholders (Table 3) i)iii)ivvv). Open access to academics and experts occurred in all sites during this period.

\subsection{Knowledge Sharing}

As a social capital element, knowledge-sharing is the ability to transfer knowledge quickly and effectively from one part of the organization to another ${ }^{19)}$. Knowledge-sharing can be evaluated by the dynamics of forum in each of the cluster industries. The main roles of forum are knowledge sharing, empowerment
Table 2 Formation of Industrial Batik Cluster

\begin{tabular}{|c|c|c|c|c|}
\hline No & $\begin{array}{c}\text { Number of Business } \\
\text { Type }\end{array}$ & $\begin{array}{c}\text { Laweyan } \\
(46)\end{array}$ & $\underset{(32)}{\text { Kauman }}$ & $\underset{(33)}{\text { Tamansari }}$ \\
\hline 1. & Workshop & $6(13.0 \%)$ & $1(3.1 \%)$ & $4(11.8 \%)$ \\
\hline 2. & Apparel & $6(13.0 \%)$ & $2(6.3 \%)$ & $5(14.7 \%)$ \\
\hline 3. & Gallery & $19(41.3 \%)$ & $26(81.3 \%)$ & $15(21.2 \%)$ \\
\hline 4. & Workshop \& Gallery & $7(15.2 \%)$ & $2(6.3 \%)$ & $7(20.6 \%)$ \\
\hline 5. & Apparel \& Gallery & $2(4.3 \%)$ & $1(3.1 \%)$ & $1(2.9 \%)$ \\
\hline 6. & $\begin{array}{l}\text { Company of Batik } \\
\text { Full Production }\end{array}$ & $6(13.0 \%)$ & - & $1(2.9 \%)$ \\
\hline № & $\begin{array}{c}\text { Number of Business } \\
\text { Location }\end{array}$ & $\begin{array}{c}\text { Laweyan } \\
(46)\end{array}$ & $\underset{(32)}{\text { Kauman }}$ & $\underset{(33)}{\text { Tamansari }}$ \\
\hline 1. & Terrace & $4(8.7 \%)$ & $12(37.5 \%)$ & $10(33.3 \%)$ \\
\hline 2. & Living/ Family Room & $16(34.8 \%)$ & $4(12.5 \%)$ & $16(45.5 \%)$ \\
\hline 3. & Special Room & $13(28.3 \%)$ & $13(40.6 \%)$ & $3(9.1 \%)$ \\
\hline 4. & Outside within Compound & $3(6.5 \%)$ & $3(9.4 \%)$ & $4(12.1 \%)$ \\
\hline 5. & Factory & $10(21.7 \%)$ & - & - \\
\hline No & Mean Size of HBE & $\begin{array}{l}\text { Laweyan } \\
(46)\end{array}$ & $\underset{(32)}{\text { Kauman }}$ & $\underset{(33)}{\text { Tamansari }}$ \\
\hline 1. & $\begin{array}{l}\text { Company of Batik } \\
\text { Full Production }\end{array}$ & $567.5 \mathrm{~m}^{2}$ & $397.2 \mathrm{~m}^{2}$ & $167.8 \mathrm{~m}^{2}$ \\
\hline 2. & Living Space \& Gallery Used & $150.3 \mathrm{~m}^{2}$ & $203.0 \mathrm{~m}^{2}$ & $135.5 \mathrm{~m}^{2}$ \\
\hline 3. & Living Space \& Workshop & $172.8 \mathrm{~m}^{2}$ & - & $82.5 \mathrm{~m}^{2}$ \\
\hline 4. & Workshop & $1114.0 \mathrm{~m}^{2}$ & - & - \\
\hline 5. & Gallery & $73.8 \mathrm{~m}^{2}$ & $120.7 \mathrm{~m}^{2}$ & - \\
\hline
\end{tabular}

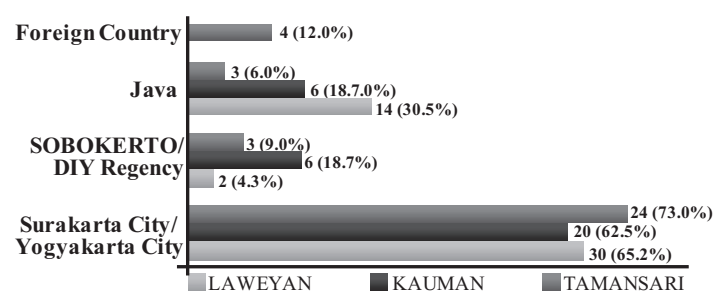

Fig. 10 Origin of Supplier

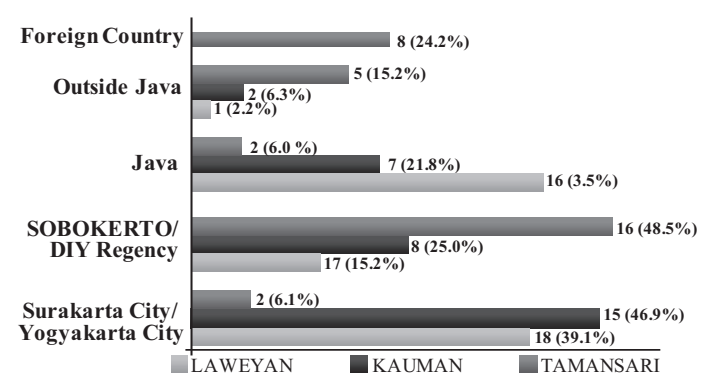

Fig. 11 Product Market Distribution

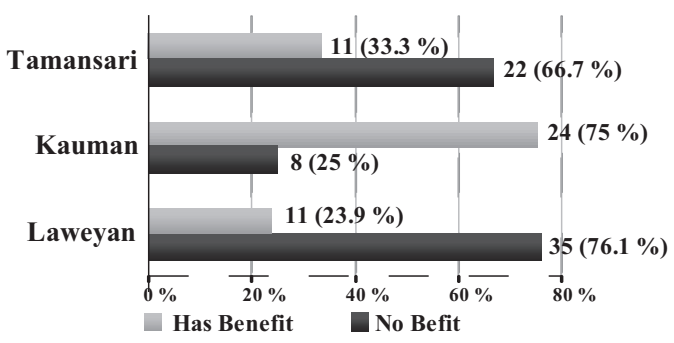

Fig. 12 Tourism Benefits 


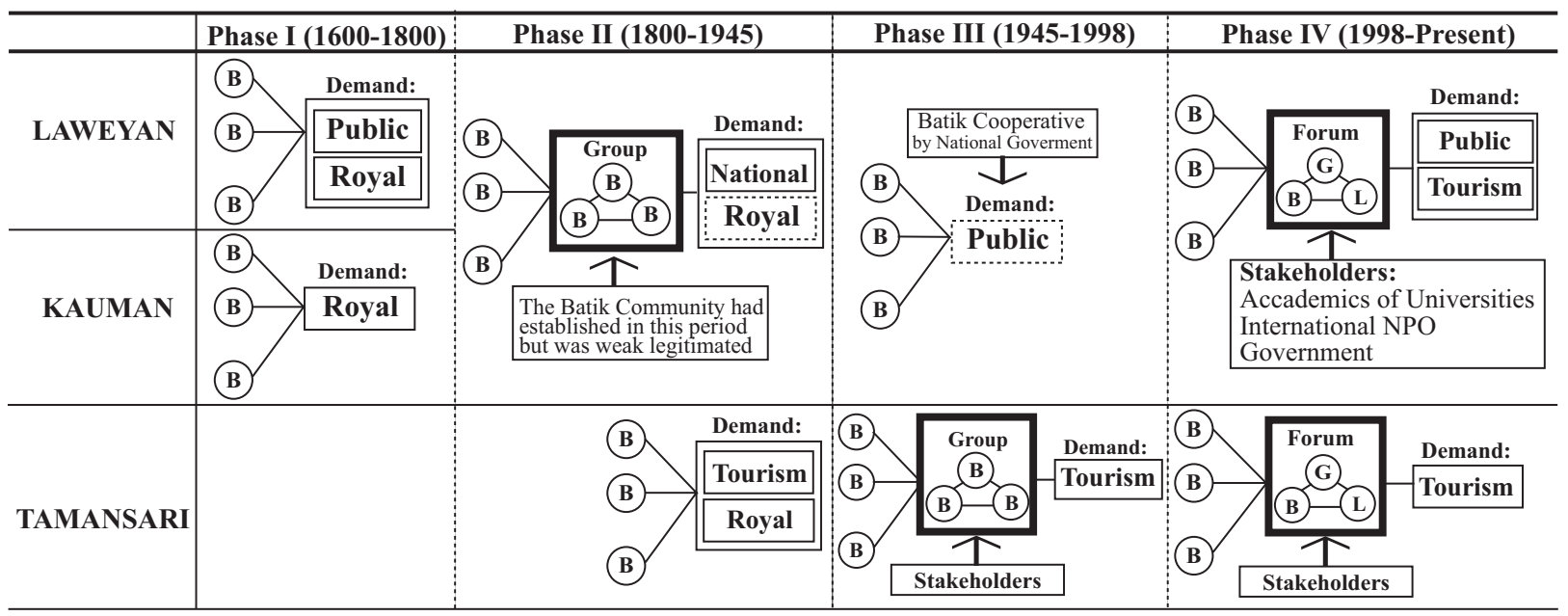

(B) Batik Entrepreneurs (G) Batik Entrepreneurs Group (L) Local Community $: \vdots$ Batik Demand weak $\square$ Batik Demand Strong $\square$ Batik Community (B) $\quad$ Communication between Batik entrepreneurs who are outside of Forum or Group

Fig. 13 Formation of the Batik Community

of local businesses, promoting tourism, organizing events and exhibitions within the site or with the partnership of the government, NPO (non-profit organization) and big enterprises. The other role of forum is negotiating the prices of products and materials with outside partners ${ }^{\mathrm{i} i \mathrm{iij} i \mathrm{iv}}$. The characteristic of forum through the statement of mission, capability of resources and management of style and transfer media type ${ }^{18)}$ were observed in order to understand the performance of knowledge-sharing. Laweyan forum has three missions, as follows: to open Laweyan as a tourism destination, to empower the Batik business members, and to strengthen the local economy $\mathrm{y}^{\mathrm{i}}$. Meanwhile in Kauman, the mission of the forum is to open Kauman as a tourism destination for Batik Industry with a religious atmosphere and to empower its members ${ }^{\text {ii) }}$. The characteristics of knowledge sharing based on the transfer media type can be formal and informal media. Formal media type is in the forms of empowerment support (training programs) and physical support with the help from the role of stakeholders (government, non government partners ${ }^{18}$. In Laweyan and Kauman, the formal media type of knowledge sharing was influenced to a large extent by expert institutions, particularly by academics from different universities ${ }^{\mathrm{i}) \mathrm{ii} \text { iiii). }}$. Kauman and Laweyan have been supported both by national and private universities in Surakarta City (Fig. 13, Table 3).

Meanwhile in Tamansari had a various formal media type support after the reviving its economy from a large earthquake in 2006. One of the reviving activities was related to empowerment of Batik industry in Tamansari $^{\text {iv) }}$, such as training Batik makers, internship programmers taught by experts and promotion taking part in exhibitions coordinated by the government and NPOs in Tamansari. Two important groups were founded before 1974; (1) Kalpika's group for Batik T-shirt product and (2) Geyong group for Batik Painting products ${ }^{\mathrm{iv})}$. Both groups have not been active since 1998-Present ${ }^{v}$. Thus, in 2008, Kampung Cyber was established for the Batik clothing and course as a forum $^{\mathrm{iv})}$. Introduced used internet for promotion of Tamansari area and selling Batik.

Informal ways of transferring knowledge sharing can happen in the forms of direct contact, mentoring, chat rooms, etc. The study found only
Table 3 Activities of the Batik Community during 2004-2011

\begin{tabular}{|c|c|c|}
\hline \multirow{5}{*}{ 突 } & ACTIVITIES & STAKEHOLDERS \\
\hline & Declaration of Laweyan as Tourism Destination 1 & (F) G(E) \\
\hline & Declaration of FPKBL in Laweyan & (F) (E) \\
\hline & $\begin{array}{l}\text { Even forTurism Promotion in Laweyan } \\
\text { "Mengenal Kampung Batik Laweyan" }\end{array}$ & (F) G \\
\hline & Training for Laweyan Guide $\bullet$ a & (F) \\
\hline \multirow{2}{*}{ 气̊ำ } & $\begin{array}{l}\text { Technical Assistance Community Based Development } \\
\text { From Academician to establish Kauman Batik Forum }\end{array}$ & (F) (E) \\
\hline & Physical Revitalitation Water Castle Tamansari @ & G(E)(B) \\
\hline \multirow{3}{*}{ 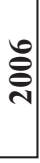 } & $\begin{array}{l}\text { Declaration of Kauman as Kampung Batik for } \\
\text { Tourism Destination }\end{array}$ & (F) (G) (E) \\
\hline & Declaration of Forum PKBK in Kauman & (F)(A) \\
\hline & $\begin{array}{l}\text { Monthly Event forTourism Promotion in Laweyan } \\
\text { "SELAWEYAN" O }\end{array}$ & (F) C) \\
\hline \multirow{3}{*}{ ક્తి } & Physical Revitalitation in Laweyan Batik Area $\boldsymbol{\Delta}$ & (F) (G) (E) C) \\
\hline & Development Batik Waste Recyling in Laweyan $\boldsymbol{\Lambda}$ & (F) GE \\
\hline & $\begin{array}{l}\text { Monthly Event for Batik - Photo Exhibition } \\
\text { in Laweyan O }\end{array}$ & (F) \\
\hline \multirow{5}{*}{ 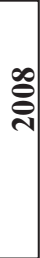 } & Physical Revitalitation \# 1 in Laweyan Batik Area & (E) G (E) C \\
\hline & Development Batik Waste Recyling in Laweyan & (E) (E) \\
\hline & $\begin{array}{l}\text { Conservation Programme for Heritage Building from } \\
\text { Local Government in Laweyan os }\end{array}$ & (F) C \\
\hline & $\begin{array}{l}\text { Annual National Event held by Surakarta City } \\
\text { Government "Solo Batik Carnival" on }\end{array}$ & (F) G (E) \\
\hline & $\begin{array}{l}\text { Estabished Kampung Cyber in Tamansari by local } \\
\text { community RT } 36 \text { RW } 09 \text { O }\end{array}$ & (C) \\
\hline \multirow{3}{*}{ } & Forum Cluster form Government in Laweyan & (F) (G) (E) \\
\hline & Internship Programme in Laweyan from University & (F) (A) \\
\hline & $\begin{array}{l}\text { Conservation Programme for Heritage Building from } \\
\text { Local Government in Kauman }\end{array}$ & (F) (G) C \\
\hline \multirow{5}{*}{ 을 } & \begin{tabular}{|l} 
Empowerment Programme in Tamansari by \\
Clean Batik Initiative, German
\end{tabular} & (g) (G) (E) \\
\hline & Internship Programme in Tamansari on & (F) (A) \\
\hline & Open Working Academician \& Forum in Laweyan & (A) (A) \\
\hline & Physical Revitalitation \# 2 in Laweyan Batik Area & (F) (E) (C) \\
\hline & Physical Revitalitation \# 1 in Kauman Batik Area $\boldsymbol{\bullet \Lambda}$ & (F) (G) (E) C \\
\hline \multirow{2}{*}{$\overline{\vec{\nu}}$} & Physical revitalitation \# 2 in Kauman Batik Area & (F) (G) (E) C \\
\hline & Building Heritage Mapping in Laweyan & (F) G (A) \\
\hline
\end{tabular}

(F)Forum (g) Group Bussiness (G) Government (A) Academician () Expert (C) Local Community - Formal Media OInformal Media $\square$ Empowerment Support $\Delta$ Physical Support 
Table 4 Comparison Element of Neighbourhood Asset Management

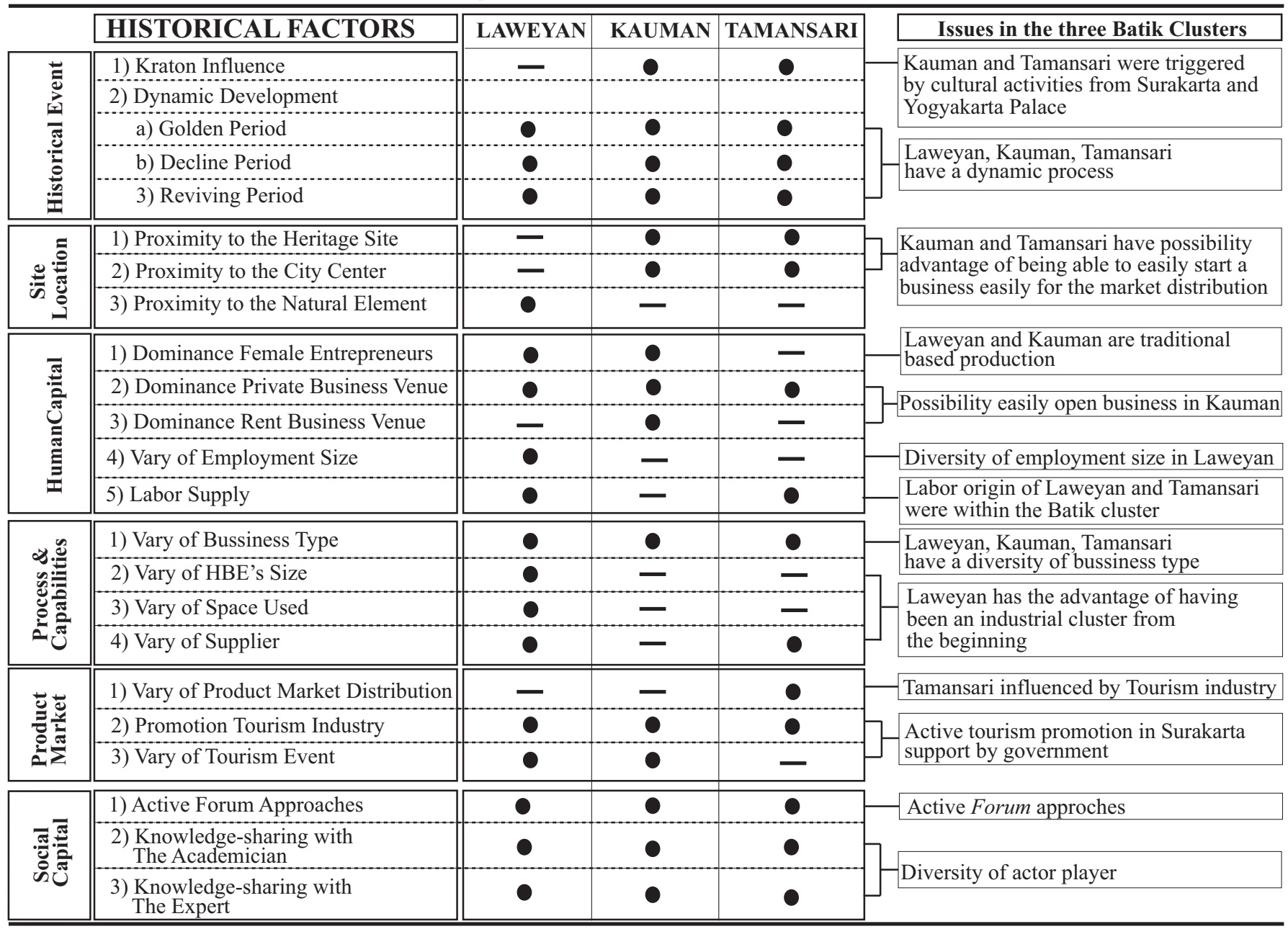

forum of Laweyan has activities to organize the informal type of knowledge sharing, such as organized the Selaweyan Event as monthly event for gathering for both business and public citizen in informal way. Even though the forum was quite active, according to the field survey in Laweyan, $87.8 \%$ of the businesses expressed that they had no benefited from forum. Meanwhile, in Kauman only $40.6 \%$ of businesses expressed that they had no benefited from forum. In Tamansari $24.2 \%$ of businesses expressed that they had not benefited from forum. In particular Kauman has the benefit from forum activities compared with other sites (Fig. 14).

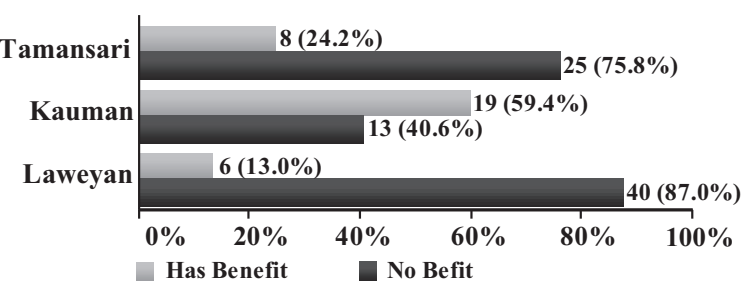

Fig. 14 Forum Benefits

\section{COMPARASION STUDIES OF NEIGHBOURHOOD ASSET MANAGEMENT}

Based on the functioning the neighborhood asset management analysis above were clarified in all three sites with the aim of identifying related issues facing each of the industrial clusters (Table 4).

\subsection{Influenced by Kingdom}

The development of Batik industry in each cluster are different. In Kauman and Tamansari, cultural activities and needs influenced the start of Batik due to their proximity to the Palace which was the center of Javanese culture. Meanwhile, Laweyan was an industrial cluster from the beginning. Throughout chronological history, all three cases studies have had a dynamic process development (golden, decline and reviving period).

\subsection{The Role of Female Managers (Mbok-mase)}

In traditional Batik production, female members of the family were the managers who ran the Batik industry. Their role had traditionally been important in the managing, marketing and promoting of Batik. The role of the mbok Mase/ female manager was a form of social structure amidst the Laweyan and Kauman class structures. This tradition is still visible both in Laweyan and Kauman where the ratio of female members is high.

\subsection{Site Location}

The benefits of site location are diverse in all three sites. Kauman in Surakarta and Tamansari in Yogyakarta are part of the castle compound and were originally occupied by royal servants (abdi dalam) (Fig. 1). Surakarta Palace and Yogyakarta Place were tourism destinations. Kauman and Tamansari have the 
added possible advantage of being able to easily start a business and having good channels for market distribution due to its proximity to the city center and tourism destinations. Meanwhile, Laweyan has the advantage of having been an industrial cluster from the beginning because it had a workshop and settlement of Batik's craftsmen. In 1997 it was designated as heritage settlement by Surakarta City government. Since then Laweyan has been a tourism destination.

\subsection{Labor Supply}

Close proximity to the labor supply is vital for the continuation of the traditional Batik industry. Traditionally, labor was supplied from peripheral agricultural areas ${ }^{4)}$. Now the origin of labor is in surrounding neighborhoods within the city and within the clusters. Laweyan has $47.8 \%$ labor origin within the cluster, while Kauman's origin of labor comes from outside Kauman, within Surakarta City (34.4\%) and outside Surakarta City (12.5\%). Meanwhile Tamansari has the highest percentage of $48.5 \%$ labor originating within the cluster (Fig. 9).

\subsection{Diversity of Business Types}

From the chronological time line analysis, Laweyan and Kauman had a strong impact on the revival process of their Batik industry. The Batik industry has become diverse. This diversity is visible in the production process, technology, organisation of businesses, and market distribution. Compared to the other sites, Laweyan has the most diverse business types within its cluster. Having the highest variation in business, Laweyan is not relying on the central business district as a market. This was visible in Laweyan by the fact that $17.4 \%$ of the owners are above 60 years old. In Kauman, the dominant business type was galleries with $81.3 \%$. It was proved that the selling method has changed from the traditional business methods. A newcomer can easily start a business in the Kauman area. Kauman has the highest percentage of rental housing (37.5\%). This proves that family inherited businesses did not continue in Kauman. Meanwhile the driving factor of the Batik industry in Tamansari was tourism.

\subsection{Diversity of Space and the Size of Home-based Enterprises}

Laweyan has a diverse number of business types, and this caused diversity in the way the space was used and the size of HBE, compared with other Batik industrial clusters. Laweyan has a diverse labor age range from 15 years old to 1 the age of 60 . Laweyan has a diverse size of laborers per business, with a percentage of more than 30 laborers per business at 23.9\%. Kauman and Tamansari do not have any businesses with more than a 30 laborer workforce.

\subsection{Diversity of Product Market and Players}

It was noted that Tamansari has a wider product market with $24.2 \%$ of product exports, and $15.2 \%$ of products sold outside the Island of Java. Other clusters still depend on local markets for the distribution of their products. This proves that geographic proximity of cluster areas combined with tourism industries may provide an open opportunity to form wider connections not only for procuring material supplies, but also for market distribution. In phase IV (1998 - present), in Laweyan and Kauman tourism influenced lot of stakeholders to be involved in Batik industry development. It can be determined that the players are not only coming from the entrepreneurs but also from community citizens and the tourism industry, such as guides, tourism agents, academics, and NPO experts.

\subsection{Critical Issues for Sustainability of Industrial Batik Clusters}

According to Stainberg ${ }^{3)}$, social aspect is related to urban revitalization. There is an urgent need for rehabilitation approaches which maintain the typical and essential qualities of the historic city areas and the life of the resident communities. This is in line with Khaerunisa ${ }^{19)}$, she has mentioned in her study of sliver craft reviving program for revitalization in Kotagede, Yogyakarta that community empowerment as social capital asset needs to be sustainability extended, thus it can save the folk heritage and build a better local economy. Hence, based on functioning of the neighborhood asset management shown in chapter 3 , it can be found that the issues facing all three sites are functioning neighbourhood asset management of the forum as a knowledge-sharing agent, and as a platform for organizing the Batik industry and managing tourism within urban heritage sites. Industrial clusters have begun to be regarded as social communities of knowledge creation and transfer. Forum is critical for knowledge-sharing within members of forum and outside partners. According to the survey, most of the entrepreneurs are not satisfied with forum functioning. To improve the effectiveness of the knowledge transfer in Batik, industrial clusters must build a solid forum. The relationship between entrepreneurs should also be fluid and solid. In addition, Laweyan can improve the tourism industry with its tangible and intangible assets of cultural identity to promote tourism. Building an area's identity around Batik production could be proposed as another alternative for tourism promotion. Meanwhile, the Tamansari cluster can revitalize the environment and atmosphere of the kampung, rather than rely only on tourists who only visit the water castle archeological site. City Governments should have policies to promote the potential of Batik industry in the heritage site to improve the quality of livelihood within the artifact heritage site.

\section{CONCLUSION}

The structured interviews, literature studies and the questionnaire surveys with Batik entrepreneurs were applied to clarify the conditions of the development phase and the functioning of neighbourhood asset management of the Batik industry. The results in this study are as follows;

1) Through time line analysis, four development phases of Batik industry and the community was clarified. (1) In phase I: the Batik production was based on handmade production. The Batik demand during this phase was from royal family demand. (2) In phase II: the introduction of stamp technology influenced Batik production and enabled the mass production. During this phase the Batik's demand was not only came from royal family but also from national demand. Although the Batik community in Surakarta City was started during this phase it was weak in legitimacy due to the political reason. And the role of Batik community was only limited to business role. (3) In phase III: as an influence of new Batik printing technology that was introduced during this phase 
the Batik's handmade production declined. Due to the changing life style Batik lost its place as the national dress. (4) In phase IV: the political environment in Indonesia has changed after the decentralization of political power. Communities' initiatives and local government policies has influenced the revival of Batik industry and Batik's handmade production after these changes. The development of tourism made Batik handmade products popular and become an essential part of revival of Batik industry.

2) The function of Batik industrial cluster in the community was clarified by analyzing elements that emerged such as: human capital, developments markets and social capital. The changing community organizations established after phase IV mostly played the role of tourism exploration as well as community empowerment in addition to its business role. Neighborhood asset management activities targeted community needs and community involvement. Among all three sites the role of female managers (Mbok-mase) remained unchanged in Kauman and Laweyan where the ratio of female members was high. It is proving that the social sustainability in both cities is concerned with the relationships between communities and the created environment.

3) The issues facing the sustainability of industrial Batik clusters in the three sites are the functioning of the forum as a knowledge-sharing agent and as a platform for organizing the Batik industry and managing tourism within urban heritage sites. The conservation of the cultural identity of the production process and local identity of settlements are vital elements of Batik marketing within urban heritage.

\section{References}

1) Allen, J.; Lylod-Jones, T.: Neighbourhood Asset Management: Life Cycles and Learning for Social Sustainability, Earthscan Publication, UK, 2010

2) Manzi, T.; Lucas, K.; Allen, J \& Lylod-Jones, T: Social Sustainability in Urban Area, Earthscan Publication, UK, 2010

3) Stainberg, F.: Conservation and Rehabilitation of Urban Heritage in Developing Countries, Habitat International Journal, No. 3. pp. 463-475, UK, 1996

4) Rebecca, M, J.: Diffused Batik Production in Central Java, A Dissertation Thesis, University of California, San Diego, 1987

5) Surakarta City Statistic Bureau: Surakarta City in Figures 2007, Surakarta, 2008 (Indonesia)

6) Kusumaningdyah, N., H.; Sakai. T.; Deguchi, A. \& Divigalpitiya, P.: The Impact of Home-Based Enterprises to Kampung Settlement Case Study of Serengan District, Surakarta, Proceeding Asian Urban Research Group, pp. 297-310, 2012

7) Yogyakarta City Statistic Bureau: Yogyakarta City in Figures 2000-2007, Yogyakarta, 2008 (Indonesia)

8) Power, A.: Neighbourhood Management and the Future of Urban Areas, Center for Analysis of Social Exclusion Paper, UK, 2004

9) Morosini, P. : Industrial Clusters, Knowledge Integration and Performance, World Development, vol. 32, pp. 305-326, Great Britain Press, 2003

10) Scott, A., J.: Industrial Organization and The Logic of Intra-Metropolitan Location, II: A Case Study of The Printed Circuits Industry in The Greater Los Angeles Region, Journal Economic Geography, vol. 59, pp. 343-67, 1983

11) Widayati, N.: Employers settlement Laweyan Batik Surakarta, Desertasi, Program Pascasarjana Fakultas Sastra Universitas Indonesia, Jakarta, 2002 (Indonesia)

12) Astuti, S.: Revitalization of Laweyan Surakarta, Vernacular Settlement Symposium, University of Indonesia, 2002

13) Ramdhon, A.: Study of Social Change-Traditional Islamic Society in Kauman, Elmatera Publisher, Surakarta, 2011

14) Wijaya, M.: Multi Commercial Economy: The Development of Socio-Economic Network Complexity of Batik Industry in Surakarta, Journal of Asian Social Science, Vol. 5, No. 8, pp. 102-110, 2009

15) Ganug, N., A.: Revival of Kampung Laweyan's Batik Industry, The Jakarta Post News Papers, Friday, 03/16/2012, accessed 03/19.2012, 2:12 PM, 2012

16) Raditya, D.: Revitalize of Tamansari, Indonesia National Geographic Magazine Article, pp. 26-31, 2011

17) Kusumaningdyah, N., H.; Deguchi, A. \& Sakai, T.: Participatory Mapping in Surakarta, Case Study of Mini Atlas Solo Kota Kita, Journal of Habitat Engineering, Vol.3, No.2, pp. 189-200, 2011

18) Bozeman, B.: Technology Transfer and Public Policy: A Review of Research and Theory, Research Policy, Elsevier, 29 (4-5), pp. 627-655, 2005

19) Khaerunisa.: Study on Folk Industry Recovary Approach by University and INGO and its Impacts to the Community Involvement in Yogyakarta, Indonesia, Journal Habitat Engineering, Vol 2, No. 2, pp. 125-134, 2010

\section{Notes}

i) Priyatmono, A.: Head of forum Pengembangan Kampung Batik Laweyan, September 7, 2011

ii) Ramdhon, A.: Academician Sebelas Maret University, Faculty of Social and Political Studies, September 15, 2011

iii) Setiawan, G.: Head of forum Kampung Batik Kauman, Surakarta, September 13, 2011

iv) Iwuk, I.: Head of forum Batik Kampung Cyber Tamansari, September 20, 2011

v) Sita: Head of the City Planning Department of Surakarta Municipality, September 11, 2011

\section{和文要約}

マタラム王国に起源を持つスラカルタ市とジョグジャカルタ市の都 市遺産に位置するバティック産業の発展段階の状況と実態を明らか にすることを主な目的として、時系列分析、バティック企業経営者 等へのインタビューアンケート調査を行った。まず、バティック産 業の発展をインドネシアの四つの時代区分における時系列分析を通 して、王室のコントロール、技術革新による近代化、観光産業の発展、 国内外の市場拡大、政府の開発政策とステイクホルダーの支援、消 費者の対象地へのアクセスと情報などが要因として影響してきたこ とを明らかにした。また、主導的組織のリーダーと地方自治体幹部
に対するインタビュー、企業経営者 111 人に対するアンケートを通 して、配置と人的資本、プロセスと能力、製品市場と観光事業の貢献、 地方自治体と政府による法的枠組み、知識の共有等を考察し、対象 地であるロウヤン、カウマン、タマンサリにおけるバティック産業 発展の実績とその組織に影響を及ぼす要因は、伝統的な家庭内生産 と女性管理者の存在、戦略的配置と労働供給、事業タイプの開発と 多様性、家庭内企業と製品市場の空間と規模等であることを示した。 さらに、産業を持続させるために企業経営者が組織し、都市遺産の 観光事業を管理する「フォーラム」の運用の実態を明らかにした。 